\title{
CAMBRIDGE
}

\section{Philosophical Papers}

Volume I: Objectivity, Relativism and Truth

Volume II: Essays on Heidegger and Others

RICHARD RORTY

Richard Rorty's collected papers, written during the $1980 \mathrm{~s}$, take up some of the issues which divide Anglo-Saxon analytic philosophers and contemporary French and German philosophers.

Volume I

f29.95 net HB $0521353696 \quad 236$ pp. f9.95 net PB 0521358779

Volume II

f29.95 net HB $052135370 \times 212 \mathrm{pp}$.

f9.95 net PB 052135878 7

\section{Plausible Worlds}

Possibility and Understanding in History and the Social Sciences GEOFFREY HAWTHORN

'Hawthorn's Plausible Worlds is not only a good read, but a book that raises very large and interesting questions about the nature of explanation in the human sciences. I found his answers to these questions persuasive.'

Richard Rorty

f27.50 net HB 0521403596208 pp.

\section{F. P. Ramsey: Philosophical Papers}

Edited by D. H. MELLOR

This volume, with a new and extensive introduction by D. H. Mellor, contains all Ramsey's previously published writings on philosophy and the foundations of mathematics. f32.50 net HB $0521374804 \quad 300 \mathrm{pp}$. f12.95 net PB 0521376211

\section{The Rise of Neo- Kantianism}

German Academic Philosophy Between Idealism and Positivism

KLAUS CHRISTIAN KÖHNKE

Translated by R. J. HOLLINGDALE Foreword by LEWIS WHITE BECK An account of the impact of 'neoKantianism' on the German academic establishment. A major contribution to the intellectual history of the nineteenth century.

f35.00 net HB $0521373360 \quad 304$ pp. Originally published by Suhrkamp Verlag

\section{Hegel: Elements of the Philosophy of Right}

Edited by ALLEN W. WOOD

Translated by H. B. NISBET

A new translation of Hegel's classic work accompanied by extensive editorial material placing the text in its historical context.

f30.00 net HB $0521344387 \quad 536$ pp. f9.95 net PB 0521348889

Cambridge Texts in the History of Political Thought

\section{Morals, Motivation and Convention}

Hume's Influential Doctrines

\section{FRANCIS SNARE}

Francis Snare subjects contemporary defenses of Humean doctrines to intense criticism and seeks to discover what versions of Hume's theories might still be defensible and viable.

f32.50 net HB $0521392616 \quad 344$ pp. Cambridge Studies in Philosophy 


\section{CAMBRIDGE}

\section{Wittgenstein}

Centenary Essays

Edited by A. PHILLIPS GRIFFITHS

In this collection, deriving from the

Royal Institute of Philosophy's lecture

series marking Wittgenstein's centenary,

fourteen contributors examine the

relevance of Wittgenstein's words and

work to contemporary thought.

f12.95 net PB $0521409470 \quad 250 \mathrm{pp}$

Royal Institute of Philosophy

Supplements 28

\section{The Philosophical Writings of Descartes}

Volume III: The Correspondence

Translated by JOHN COTTINGHAM, ROBERT STOOTHOFF, DUGLAD MURDOCH and ANTHONY KENNY

Volumes I and II provide a completely new translation of the philosophical works of Descartes with volume III containing 207 of Descartes' letters. f45.00 net HB $0521403235 \quad 432 \mathrm{pp}$. f14.95 net PB 0521423503

\section{On the Nature and Existence of God}

\section{RICHARD GALE}

In considering arguments for and against the existence of God, Gale is able to clarify many important philosophical concepts including exploration, time, free will, personhood, actuality, and the objectivity of experience. f35.00 net HB $0521403006 \quad 432$ pp.

\section{The Semantic Tradition from Kant to Carnap}

To the Vienna Station

The late J. ALBERTO COFFA

Edited by LINDA WESSELS

This major publication is a history of the semantic tradition in philosophy from the early nineteenth century through its incarnation in the work of the Vienna Circle of logical positivists.

f35.00 net HB $0521374294 \quad 464$ pp.

\section{Hegel's Political Theology} ANDREW SHANKS

This study attempts to grasp the continuing contemporary relevance of Hegel's political theology, which the author interprets as a uniquely radical critique of every sort of religious authoritarianism.

f32.50 net HB $0521403219 \quad 248$ pp.

\section{Knowledge in Perspective}

Selected Essays in Epistemology ERNEST SOSA

Ever since Plato, philosophers have faced one central question: what is the scope and nature of human knowledge? In this volume, distinguished philosopher Ernest Sosa collects essays on this subject written over a period of twenty-five years.

f3́2.50 net HB $0521356288 \quad 250$ pp.

⿷10.95 net PB 0521396433

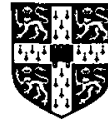

\section{CAMBRIDGE UNIVERSITY PRESS}

The Edinburgh Building, Cambridge, CB2 2RU. 


\section{CAMBRIDGE}

The Metaphysics of Morals

IMMANUEL KANT

Translated by MARY GREGOR

The only complete translation of Kant's major work in applied moral philosophy in which he deals with the basic principles of rights and of virtues. f30.00 net HB $0521303729 \quad 400$ pp. f10.95 net PB $052131657 X$

Texts in German Philosophy

\section{Political Theory and Postmodernism}

STEPHEN K. WHITE

Stephen White explores the work of Heidegger, Foucault, Derrida, Lyotard and Habermas, as well as 'difference' feminists, with the goal of showing how postmodernism can inform contemporary ethical-political reflection.

f25.00 net HB $0521401224 \quad 180$ pp.

f9.95 net PB 0521409489

Modern European Philosophy

\section{Consciousness and Revolution in Soviet Philosophy}

From the Bolsheviks to Evald Ilyenkov DAVID BAKHURST

David Bakhurst offers a unique insight into the world of Soviet philosophy by offering the first substantial treatment of a Soviet philosopher's work (Evald Ilyenkov) by a Western author. £27.50 net HB $0521385342 \quad 288$ pp. f9.95 net PB 0521407109 Modern European Philosophy

\section{Nietzsche on Truth and Philosophy}

\section{MAUDEMARIE CLARK}

A lucid and penetrating analytical account of all the central topics of Nietzsche's epistemology and metaphysics, including his views on truth and language.

f30.00 net $\quad H B \quad 0521343682 \quad 220 \mathrm{pp}$.
f10.95 net PB 0521384501
Modern European Philosophy

\section{Nietzsche contra Rousseau}

A Study of Nietzsche's Moral and Political Thought

\section{KEITH ANSELL-PEARSON}

Keith Ansell-Pearson takes a serious look at Nietzsche as a political thinker and relates his political ideas to the dominant traditions of modern political thought. f35.00 net HB $0521411734 \quad 300 \mathrm{pp}$.

\section{The Language of Art History}

\section{Edited by SALIM KEMAL and IVAN GASKELL}

This first volume in a new series offers a range of responses by distinguished philosophers and art historians to some crucial issues generated by the relationship between the art object and language in art history.

f32.50 net HB $052135384 \times 262 \mathrm{pp}$. 7 half-tones

Cambridge Studies in Philosophy and the Arts

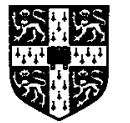

\section{CAMBRIDGE}

UNIVERSITY PRESS

The Edinburgh Building, Cambridge, CB2 2RU. 


\section{CAMBRIDGE}

Now in paperback

\section{Trials and Punishments}

R. A. DUFF

R. A. Duff suggests that punishment can be understood as a communicative attempt to bring a wrong-doer to repent his crime.

'... incisive and persuasive ...'

The Times Literary Suppleme
$\mathrm{f} 12.95$ net PB $0521407613336 \mathrm{pp}$.

\section{Liberal Purposes}

Goods, Virtues and Diversity in the Liberal State

\section{WILLIAM A. GALSTON}

Professor Galston argues that the modern liberal state is committed to a distinctive conception of the human good, and to that end has developed characteristic institutions and practices in the pursuit of specific public purposes that give unity to the liberal state.

f 30.00 net HB $0521410363 \quad 348$ pp. f 11.95 net PB 0521422507

Cambridge Studies in Philosophy and Public Policy

\section{Automatism, Insanity and the Psychology of Criminal Responsibility}

A Philosophical Inquiry ROBERT F. SCHOPP

Robert Schopp provides a conceptual framework that allows us to understand the significance of psychological states and processes for the attribution of criminal responsibility.

f 30.00 net HB $052140150 \times \quad 288 \mathrm{pp}$. Cambridge Studies in Philosophy and Law

\section{Violence, Terrorism and Justice}

Edited by R. G. FREY and

CHRISTOPHER MORRIS

A group of distinguished moral and social thinkers address the urgent problem of terrorism, discussing whether the assessment of terrorist violence should be based on its consequences, and exploring what means may be used to combat those who use violence without justification.

£35.00 net HB 0521401259

f12.95 net PB 0521409500

Cambridge Studies in Philosophy and Public Policy

\section{Liability and Responsibility}

Essays in Law and Morals

Edited by R. G. FREY and CHRISTOPHER MORRIS

This collection of essays by a group of well-known philosophers and legal theorists covers various topics in the philosophy of law, focusing on issues concerning liability in contract, tort and criminal law.

f37.50 net HB $0521392160 \quad 350$ pp. Cambridge Studies in Philosophy and Law

\section{Risky Business}

Genetic Testing and Exclusionary Practices in the Hazardous Workplace ELAINE DRAPER

Risky Business analyses health screening in the workplace, at a time when more corporate employers are using genetic information as a cornerstone of their hiring practices. £30.00 net HB 0521370272304 pp. f11.95 net PB 0521422485 Cambridge Studies in Philosophy and Public Policy

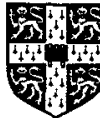

\section{CAMBRIDGE UNIVERSITY PRESS}

The Edinburgh Building, Cambridge, CB2 2RU. 


\section{CAMBRIDGE}

Now in paperback

\section{Knowledge and Evidence}

PAUL K. MOSER

'Moser defends a foundationalist epistemology and a version of the correspondence theory of truth.'

The Times Higher Education Supplement f13.95 net PB 0521423635285 pp. Cambridge Studies in Philosophy

\section{Sensations}

A Defense of Type Materialism CHRISTOPHER S. HILL

This book confronts a whole series of metaphysical and epistemological questions and presents an argument for type materialism.

f29.95 net HB 0521394236256 pp. f10.95 net PB 0521397375

Cambridge Studies in Philosophy

\section{A Morally Deep World}

An Essay on Moral Significance and Environmental Ethics

\section{LAWRENCE E. JOHNSON}

Lawerence Johnson advocates a major change in our attitude towards the nonhuman world by arguing that non-human animals are morally significant beings with interests and rights. f27.95 net HB $0521393108 \quad 180 \mathrm{pp}$.

\section{Democracy and the Market}

Political and Economic Reforms in Eastern Europe and Latin America ADAM PRZEWORSKI

This major book analyses recent events in Eastern Europe and Larin America, focusing on transitions to democracy and market-oriented economic reforms. f27.50 net HB $0521412250 \quad 200$ pp. 2 tables, 8 line diagrams

f9.95 net PB $052142335 X$ Studies in Rationality and Social Change

\section{Interpersonal Comparisons of Well-Being}

Edited by JON ELSTER and JOHN ROEMER

A diverse group of economists, philosophers, political scientists and psychologists address the problems, principles and practices involved in comparing the well-being of different individuals.

f35.00 net HB $0521392748 \quad 496$ pp. Studies in Rationality and Social Change

The Times Higher Education Supplement f10.95 net PB 0521395666288 pp.

\section{CAMBRIDGE UNIVERSITY PRESS}

The Edinburgh Building, Cambridge, CB2 2RU. 


\section{CAMBRIDGE}

Understanding Action

An Essay on Reasons

FREDERIC SCHICK

Professor Schick looks at the reasons people have for their actions, how people see or understand theit situations, options and prospects, and thus expands the current theory of decision and action. f25.00 net HB $0521403308 \quad 192$ pp. f8.95 net PB 0521408865

\section{Now in paperback}

\section{Spectacles and Predicaments}

Essays in Social Theory

ERNEST GELLNER

Ernest Gellner develops a political and social philosophy which answers some of the theoretical and practical 'predicaments' of the world in which we live.

f14.95 net PB $0521424348 \quad 394$ pp.

\section{Autonomy and Self-Respect}

THOMAS E. HILL, Jr.

This stimulating collection of essays in ethics focuses on everyday moral issues, often neglected by philosophers, and explores the deeper theoretical questions which they raise.

$£ 27.50$ net HB $0521394643 \quad 208$ pp. f9.95 net PB 0521397723

\section{Ethnomethodology and} the Human Sciences

Edited by GRAHAM BUTTON

The contributors in this book reappraise the significance of ethnomethodology in sociology and the human sciences.

f42.50 net HB $0521380480 \quad 320 \mathrm{pp}$. f16.95 net PB 0521389526

\section{Probabilistic Causality}

\section{ELLERY EELLS}

In this important first book in the series Cambridge Studies in Probability, Induction and Decision Theory, Ellery Eells explores and refines current philosophical conceptions of probabilistic causality. f32.50 net HB $0521392446 \quad 375$ pp. 45 line diagrams Cambridge Studies in Probability, Induction and Decision Theory

\section{Atoms, Pneuma and Tranquillity}

Epicurean and Stoic Themes in European Thought

MARGARET J. OSLER

Addresses the question of the influence that Epicureanism and Stoicism exerted on the development of European thought from classical times to the Enlightenment.

f32.50 net HB $0521400481288 \mathrm{pp}$. 1991

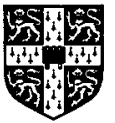

\section{CAMBRIDGE}

UNIVERSITY PRESS

The Edinburgh Building, Cambridge, CB2 2RU. 


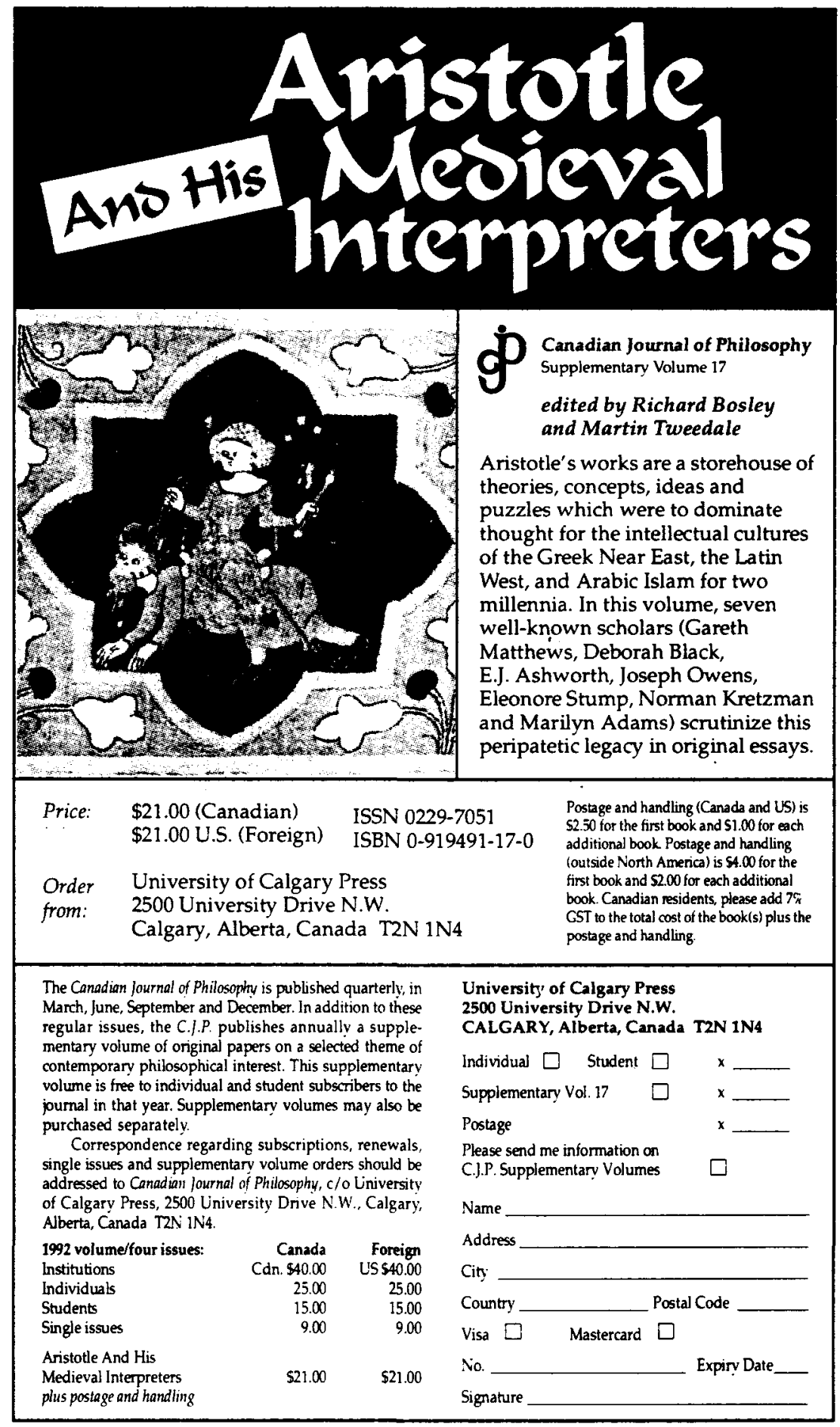




\section{Revolution and Human Rights}

Edited by Werner Maihofer and Gerhard Sprenger

1990. 266 pages (Archiv für Rechts- und Sozialphilosophie, Beiheft 41). Pp. DM 98,-

Contents:

I. Revolution and Law: H.P. Glenn: Law, Revolution and Rights - M.A.Simon: Must a Revolution Preserve Rights? -C. Wellman: Locke's Right to Revolution Reexamined - W.E. Mumion: Aquinas on Revolution-Shing-I Liu: Menschenrecht, Widerstandsrecht u. Revolution - II. Human Rights and Democracy: A. Mineau: L'origine des droits del homme-H.Köchler:Menschenrechtskonformitalt demokrat. Systeme - M. Scheinin: Legal Protection of Human Rights and Different Conceptions of Democracy - J.F. Doyle: Fulfilling Revolutionary Promises - N. Lopez-Calera: Naturaleza dialectica de los derechos humanos-J. Wetlesen: Inherent Dignity as a Ground of Human Rights - M.-R. Ollila: Virtue Ethics and Violations of Human Rights - P. Durán y Lalaguna: Human Rights in Democratic Society - C.B. Gray: Fratemity and Nonobstante - III. Human Rights and International Law: A. Bragyova: Is it Possible to Base Human Rights on Intemaional Law? - L Lukaszuk: The Concept of Protection of Human and Civic Rights According to the Principles and Rules of Both the Intemational and Constitutional Law - A.N. Georgiadou: Les droits fondamentaux en droit communautaire-IV. Human Rights and Socialism: K.A.Mollnau: Entwicklungsdenken in derRechtswissenschaft -W.Sokolewicz: Constitutionality as a Precondition of the Rule of Law R. Wienuszewski: The Principle of Interrelation Between Human Rights and Duties - P.D. Swan: The Contributions of J. Habermas and C. LefortA. Lopatka: Revolution and Socialist Renewal in Poland - M. Samu: The Connection Between Human Rights and Democracy - D.J. Galligan: The Foundations of Due Process in Socialism - $R$ Bellamy: Liberal Rights and Socialist Goals

\section{Law and the States in modern Times}

Edited by Werner Malhofer and Gerhard Sprenger

1990.232 pages (Archiv für Rechts- und Sozialphilosophie, Beiheft 42). Pp. DM 90,-

Contents:

Preface - I. Theories of State: R. Martin: Democracy and Rights: Two Perspectives-G.den Hartogh: The Limits of Liberal Neutrality-M. Blegvad: Types of Liberal Theories of Justice and Democracy-P. Gérard: Ethique et politiquedans la légitimation du droit - A. Perenic: La primauté del'individu ou la primauté du système politiqueE. Wolgast: The State as Servant - V. Haksar. Social Contract, Integrity and the Right to Equal Liberties - II. Theories of Law: J. Cottingham: The Philosophical Status of Natural Rights-T.A. Fay: Rights and Natural Law - S. Morimura: Social Morality and Right-Based Moralities-M. D. Bayles: Against Right-Based Moral TheoriesC. Johnson: On Some Alleged Difficulties for Utilitarian Justifications of Rights - H. v. Erp: Democracy: Pragmatic Conceptions and Ethical Justification-A. M. Cameron:MacCormick's Liberal Theory of Rights - F. A. Cappelletti: De la slibre pensées au droit à la ulibre communication des pensées et des opinions»-H. Collins: Liberty and Equality in the Workplace - B. B. Levenbook: Are There Any Positive Rights? - H. T. Klami: All Things Not Considered - R. Alexy: Problems of Discursive Rationality in Law - A. Aamio: Taking Rules Seriously - J.-P. Rentuo: Obligation to Obey? - A. MacLeod: Rights, Constraints and Consequences - I. Williams: Legal Rights and Privacy in the Information Society — List of Contributors 


\title{
ALETHEIA
}

\section{AN INTERNATIONAL JOURNAL OF PHILOSOPHY}

\section{VOLUME V \\ TRUTH AND VALUE: THE PHILOSOPHY OF DIETRICH VON HILDEBRAND}

\author{
ISBN 3-261-04451-9 \\ Bern, Frankfurt/M., New York, Paris, 1992. 450 pp. \\ pb. sFr. 98.- / $\$ 67.80$
}

Edmund Husserl has said of Hildebrand's doctoral thesis which appeared in the Jahrbuch für Philosophie und phänomenologische Forschung as «Die Idee der sittlichen Handlung :» «I can only propose for this important work the predicate opus eximium (of the highest excellence).»"

This volume comprises the most complete secondary resource on the thought of Dietrich von Hildebrand, the background of his phenomenological realism, and its relation to the thought of other important thinkers such as Kant, Marcel, St. Thomas, and Nietzsche.

The issue contains a previously unpublished work by Edmund Husserl, and a commentary by Karl Schuhmann concerning the relation between Husserl and Hildebrand. Also included, and of interest to a variety of readers, is a historical treatise on the fight which Hildebrand led against the Nazi party, a fight which forced him into exile and nearly cost him his life. The most complete bibliography of Hildebrand's writings is included as a tool to further research in the philosophy of Hildebrand.

When one considers the quality, breadth, and sheer quantity of Hildebrand's writings, it is astonishing that his writings have received so little attention. It is hoped that this issue will further the thought of this thinker who was so highly esteemed by the like of Edmund Husserl, Max Scheler, Adolf Reinach and Gabriel Marcel.

PETER LANG AG

Europäischer Verlag der Wissenschaften

Jupiterstr. 15 - Postfach 277 CH-3000 Bern 15/Schweiz

Telefon: $031 / 9411122$

Fax : $031 / 9411131$

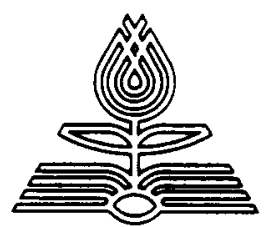

PETER LANG PUBLISHING, INC.

62 West 45 th Street USA - New York, NY 10036 Phone : $212764 \cdot 1471 / 1472$ Fax: $212302-7574$ 


\section{PHILOSOPHIA}

Philosophical Quarterly of Israel

Editor: Asa Kasher

\section{Articles from Volume 21, 1991-1992}

Isaac Nevo: What Price Deconstruction?

Derrida on Heidegger and the Question of Nazism: A Critical Study

Fred Feldman: The Enigma of Death

Michael Wreen: Abortion and Pregnancy due to Rape

Charles Taliaferro: Imaginary Evil: A Skeptic's Wager

Sven Ove Hansson: The Paradox of the Believer

Richard 1. Kirkham: On Paradoxes and A Surprise Exam

Howard Burdick: Non-Essentialistic Modal Logic

Robert Dunn: Reasons, Attitudes and the Breakdown of Reasons

Steve Edwards: Formulating a Plausible Relativism

James E. Taylor: Scepticism and the Nature of Knowledge

Series: On "Error"

4. Leslie Armour: Error and the Idealist

5. V.L. McGeer: The Problem of Error: A Surd Spot in Rational Intentionalism

6. Ehud Rahat: Metaphors and Malapropisms

7. Michael P. Levine: Berkeley: How to Make a Mistake

Next Series: On Emotions

Discussions, Critical Studies, Book Reviews

Editorial addresses:

PHILOSOPHIA, Bar-Ilan University, Ramat-Gan 52100, Israel Prof. Asa Kasher, A. Horodisch Chair of Philosophy of Language, Tel-Aviv University, Tel-Aviv 69978, Israel 


\section{Are you concerned about today's social and political problems?}

\section{Then SOCIETY is for you!}

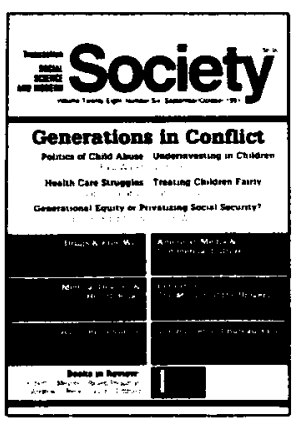

Editor-in-Chief

IRVING LOUIS HOROWITZ

Senior Editors

HOWARD S. BECKER

NATHANIEL J. PALLONE

AARON WILDAVSKY

Managing Editor

BRIGITTE M. GOLDSTEIN

Special Editors

DAVID K. HART

(Book Roviviw Editor)

DOUGLAS HARPER

(Photo Editor)

ARTHUR ASA BERGER

(Film and Telovision Reviaw Edior)

\section{ADVISORY BOARD}

DANIEL YANKELOVICH

The Daniel Yankabovich Group

SEYMOUR MARTIN UIPSET,

Stantord University

MICHAEL CURTIS,

Rutgers University

CHARLES C. MOSKOS,

Nordtwestem University
Since 1963, SOCIETY has been at the center of debate on the major social and political issues of our day. Operating out of the deep conviction that real-world problems matter, SOCIETY responds to the changing needs and concerns of a sophisticated readership that demands fearless, penetrating analysis of the social attitudes and political beliefs underlying the headlines.

Six times a year, SOCIETY brings you clear thinking and perceptive analysis, presented in readable articles and special features by leading social scientists. It is the publication of choice for those who want to look beyond their personal and profes. sional worlds into a larger arena where key thinkers address - fundamental issues that concern us all.

\section{ASSOCIATE EDITORS}

UNDA H. AIKEN
DANIEL BELL
PETER LERGER
AMITAI ETZIONI
WILIAM FORM
CARL GERSHMAN
JEANNE GUIUEMIN
NATHAN KEYFIT
MICHAEL KIMMEL
MARCEL C. LaFOULIETE
GERHARD LENSKI

WIUAM MCCORD WLSON CAAEY MCWILLAMS DOROTHY NELVAN RICHARD JOHN NEUHAUS KENNETH PREWTTT ROBERT F. RICH RAYC. RIST KENNETHW. THOMPSON BERNARD L WEINSTEIN CAROL H. WEISS JAMES D. WRIGHT

\section{Subscription Rates Individuals: $\$ 36 / \mathrm{yr} ; \$ 66 / 2 y r s ; \$ 90 / 3 y r s$ Institutions: $\$ 78 / y r ; \$ 144 / 2 y r s ; 198 / 3 y r s$ Domestic first-class add \$20/yr Foreign surface mail add $\$ 24 / y r$ Foreign airmail add $\$ 48 / y r$ Published bimonthly, six times a year ISSN 0147-2011}




\title{
THE PHILOSOPHICAL QUARTERLY
}

\author{
Edited in the University of St Andrews \\ Chairman of the Board of Editors: NEIL COOPER \\ Executioe Editor: ROGER SQUIRES \\ Reviews Editor: JOHN HALDANE
}

Founded in 1950, the Quarterly is one of the best established journals in the field. It aims to publish significant papers in all branches of the subject, discussions of new philosophical work, reviews of books and book notes.

\section{Recent articles and discussions include:}

- All The Difference In The World

Tim Crane

- Visual Fictions

- Is There Higher-Order Vagueness? Gregory Currie

- Thoughts Which Only I Can Think Mark Sainsbury Recent Reviews by

CJF Williams

Elizabeth Anscombe, Tom Baldwin, Edward Craig, Stephen Darwall, Michaed Dummett, Antony Flew, Graeme Forbes, David Hamlyn, John Heil, Jennifer Hornsby, Anthony Kenny, Alasdair Maclntyre, Mary Midgley, Harold Noonan, Roger Scruton and Charles Travis

ORDER FORM

Subscription Rates, Volume 42, 1992 ISSN 0031-8094

Canedien customen should add 7\% OST

Individuals $\mathbf{2 1 7 . 0 0}$ (UK/Europe), $\mathbf{\$ 3 6 . 5 0}$ (North America), $\mathbf{2 1 . 5 0}$ (Elsewhere)

Instututions $\mathbf{5 4 6 . 0 0}$ (UK/Europe), $\$ 105.00$ (North America), $\mathbf{6 6 2 . 0 0}$ (Elsewhere)

$\square$ Please enter my subscription/send me a sample copy

$\square \quad$ I enclose a cheque/money order made payable to Basil Blackwell Ltd Please charge my Access/American Express/Mastercard/Eurocand

Card Number Expiry Date

For payments via the National Girobank, the Basil Blackwell account number is 2366053 Name

Address

Post Code

Signature Date

Payment must accompany orders

Please retum this form to: Marketing Manager, Blackwell Publishers, 108 Cowley Road, Oxford, OX41JF, UK Registered Na. 180277.

Or to: Marketing Manager, Blackwell Publishers, Three Cambridge Center, Cambridge, MA 02142, USA

Blackwell Publishers, Oxford UK and Cambridge USA 


\section{PHILOSOPHICAL INVESTIGATIONS}

Edited by D Z Phillips

Philosophical Investigations

has developed a tradition of

publishing scholarly and

thought-provoking articles in all branches of philosophy.

These articles are

complemented by a

Discussion section and an

extensive Book Review

section. Special issues are

occasionally published.
Recent articles include:

Conquering Chance

Grete Henry-Hermann

Wittgenstein on Tolstoy's What is Art?

$R W$ Beardsmore

Legitimacy and Trust

Olli Lagerspetz

Smooth and Rough Logic

Laurence Goldstein

Special Issues: on Norman

Malcolm and Martha Nussbaum

\section{ORDER FORM}

Subscription Rates, Volume 15, 1992

PHILOSOPHICAL INVESTIGATIONS ISSN 0190-0536

Individuals $\mathbf{2 7 . 5 0}$ (UK/Europe), $\$ 56.00$ (N America), 833.00 (Rest of World)

Institutions 264.00 (UK/Europe), $\$ 137.00$ (N America), 881.00 (Rest of Worid)

Published quarterly

$\square \quad$ Please enter my subscription/send me a sample copy

I enclose a cheque/money order payable to Basil Blackwell

Please charge my Access/American Express/Diners

Club/Mastercard/Nisa account number

Expiry Date

For payments via the National Girobank, the Blackwell account number is 2366053

Name

Address

Postcode

Signature

Date

Payment must accompany orders

Please retum this form to: Journals Marketing, Blackwell Publishers, 108 Cowley Road, Oxford, OX4 1JF, England. Registered No. 180277. Or to: Journals Marketing. PHIN. Blackwell Publishers. Throe Cambridge Conter, Cambridge, MA 02142, USA 


\section{PHILOSOPHY NQWV}

A magazine for people interested in Western philosophy. Issue 3 includes articles on free will and determinism, on the ethics of abortion and on the state of philosophy in Russia, as well as humour, letters and book reviews.

Issue 3 is out now, and is available at $£ 1.90$ from selected newsagents and bookshops, or by subscription from the publishers. Why not let us rush you a copy today?

Please send me :

* Issue 3 of Philosophy Now. I enclose a cheque for $£ 1.90$ inc. post and packing.

* Issues 3 to 8 inclusive. I enclose a cheque for $£ 10.50$ inc. post and packing.

(Delete as appropriate)

Name

Address.

Postcode.

Please make cheques payable to 'Philosophy Now' and send to Philosophy Now, 226 Bramford Road, Ipswich IP1 4AS

If you are interested in writing for Philosophy Now, please ask for a copy of our 'Guide for Authors'.

Philosophy Now - It Makes You Think!

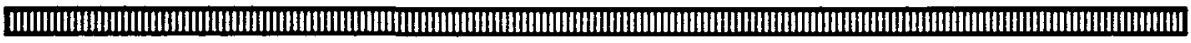




\section{Information for Authors}

Prospective authors should send their contributions, typed and double-spaced on quarto or A4 paper, to the Editor, Mr Renford Bambrough, Royal Institute of Philosophy, 14 Gordon Square, London WC1H 0AG. They should retain a second copy for the purpose of checking proofs. Articles submitted should conform to Hart's Rules for Compositors and Readers (Oxford University Press, 1967). The Editor may alter manuscripts wherever necessary to make them conform to the stylistic and bibliographical conventions of the journal. Single quotation marks should be used except where there is a quotation within another. The titles of books and journals should be underlined (i.e. to be printed in italics), as should foreign words. Titles of articles should be in single quotation marks.

Notes and references will be printed as footnotes and should be typed (double-spacing) on a separate sheet, numbered consecutively. They should be referred to in the text by superscripts. Citations should be as follows:

${ }^{1}$ H. B. Acton, The Philosophy of Punishment (London: Macmillan, 1969), 192-198.

${ }^{2}$ R. S. Downie and Elizabeth Telfer, 'Autonomy', Philosophy 46, No. 178 (October 1971), 295.

${ }^{3}$ Op. cit. note $1,101-112$.

${ }^{4}$ W. C. Wimsatt, 'Some Problems with the Concept of Feedback', Boston Studies in the Philosophy of Science, VIII, R. C. Buck and R. S. Cohen (eds.) (Dordrecht: D. Reidel, 1971), 242.

The return of contributions cannot be guaranteed unless they are accompanied by stamps, or in the case of contributions from abroad, by international coupons, to cover postage. A self-addressed envelope should also be enclosed.

Only corrections of printer's errors can be allowed in proofs. Authors are therefore asked to send any alterations or additions to $\mathrm{Mr}$ Bambrough as soon as possible after receiving his letter of acceptance.

Authors of articles, discussion papers and review articles will receive twenty-five offprints free of charge. Additional offprints can be ordered when proofs are returned by arrangement with the Institute.

Books for review should be sent to the Editor at the Institute and not to Cambridge University Press. Publishers are asked to note that nonphilosophical works are not reviewed in Philosophy.

Authors' corrected proofs should be sent to Mr Bambrough at St John's College, Cambridge. All other correspondence should be addressed to the Institute and not to any address in Cambridge. 


\section{Philosophy}

VOLUME 67 NO 261 JULY 1992

Editorial: What the Butler Said 281

Solitary Rule-Following-T. s. CHAMPLIN 285

Induction: A Non-Sceptical Humean Solution- JOHN O. NELSON 307

Language and the Society of Others - GUY ROBINSON 329

McTaggart at the Movies - GREGORY CURRIE 343

Philosophy and its History - FREDERICK COPLESTON 357

Wholes, Parts, and Infinite Collections- P. O. JOHNSON 367

Discussion

A Reply to Crude and Reckless Distortions - PAUL EDWARDS 381

The Unbearable Lightness of Deconstruction - FRANK G. VERGES 386

James Giles on Personal Identity - ANTONY FLEW 394

More on Moral Dilemmas- j. p. DAY 399

New Books

Reviews 407

Booknotes 419

Books Received 421

$\begin{array}{ll}\text { Notebook } & 426\end{array}$

(C) The Royal Institute of Philosophy 1992

CAMBRIDGE UNIVERSITY PRESS

The Pitt Building, Trumpington Street, Cambridge CB2 1RP 40 West 20th Street, New York, NY 10011-4211, USA 10 Stamford Road, Oakleigh, Victoria 3166, Australia 